\title{
Chapter 1 \\ Rural World, Migration, and Agriculture in Mediterranean EU: An Introduction
}

This book investigates the dynamics that are reshaping human and natural landscapes in the European agrarian world, with a specific focus on Mediterranean Europe. We focus here on more marginal rural settings, where the potential for agricultural intensification is structurally limited. These areas in particular have suffered from the geographical and socio-economic polarization of development patterns and have paid a relevant burden to the recent crisis.

In these areas, immigration has, to an extent, helped counterbalance the dynamics of an ageing and declining local population, with immigrant communities today relevant not only as an agricultural workforce, but also as new citizens of rural communities.

Contemporary migrations from and to rural areas are to be analysed in relation to the incorporation of agrarian systems into global markets, agricultural governance, and local territories' struggle between innovation and resilience.

Disentangling the critical relationships between the conditions of agricultural work, rural development paradigms, labour markets, and migration policies represents a necessary step to understand the ongoing dynamics of rural mobility and to suggest opportunities and solutions that might accommodate the different interests and needs in Mediterranean societies. The interface between agriculture and migration is fertile, not only in academic terms, but also in socio-economic and political ones. 


\subsection{Scope and Aims of the Book ${ }^{1}$}

This book aims to introduce students and practitioners to migration from the perspective of agriculture and rural development. Intense territorial polarizations in recent decades and the resulting reconfiguration of the agrarian world have resulted in emigration increasingly representing a key livelihood strategy for rural households. Today, across the globe, rural youth seek better conditions and opportunities often away from their communities of origin. The implications for rural development are diverse and controversial, in social, economic, as well as environmental terms.

The Mediterranean represents an appropriate setting for exploring the interfaces between migratory flows, agriculture, and rural development in a wider perspective as the region is simultaneously an area of emigration, immigration, and transit for migrants. Migration is not new here, as the Mediterranean is historically at the crossroads of three continents, with mobility characterized by different triggers, pace, and trajectories in diverse periods.

This book focuses on the specificities of the agrarian world in the Mediterranean $\mathrm{EU}$, which is increasingly populated by immigrants who originate from poorer southern and eastern regions and who have come to live and work in the European countryside. Its chapters analyse the role of migratory flows in tackling the social and economic mismatch of rural labour markets in critical societal domains such as the production of food and the management of natural resources.

In more marginal rural settings, where the potential for agricultural intensification is structurally limited and the consequences from recent economic shocks are higher, immigrant communities play a particularly important role in filling the socioeconomic gaps left by the national population.

These dynamics seem to reproduce patterns of mobility typical of the agrarian world and represent an invaluable opportunity for territories and sectors that would otherwise face abandonment and desertification. The significance of immigrant communities notwithstanding, there are problems with their recognition and integration as both agricultural workers and as rural citizens.

After offering a broad overview of the restructuring patterns that have affected agriculture and rural areas in the EU, this book analyses contemporary rural

\footnotetext{
${ }^{1}$ This book is the result of joint and equal contributions by the authors.

In Chap. 1, Sects. 1.1 and 1.2 should be attributed to Michele Nori. Sections 1.3 and 1.4 to Domenica Farinella.

In Chap. 2, Sects 2.1, 2.2 and 2.3 should be attributed to Domenica Farinella. Sections 2.4 and 2.5 to both authors.

In Chap. 3, Sects 3.1, 3.6.1, 3.6.2 and Appendix 1 should be attributed to Michele Nori. Sections 3.3, 3.5, 3.6.3 and 3.7 should be attributed to Domenica Farinella. Sections 3.2 and 3.4 to both authors.

In Chap. 4, Sect. 4.1 should be attributed to Michele Nori. Sections 4.3 and 4.4 to Domenica Farinella. Section 4.2 and 4.5 to both authors.

Chap. 5 should be attributed to Michele Nori.

Both authors contributed equally to Chap. 6 and Conclusions.
} 
migrations and the emergence of immigrants in relation to the incorporation of agrarian systems into global markets and European agricultural governance.

Set between tradition, innovation, and resilience, rural areas express in fact the contemporary contradictions of the neoliberal global world. On the one hand, these are the site of exodus, population decline, economic crisis, and land abandonment or overexploitation. On the other, these represent the space for local movements for autonomy, peasant agriculture, and rural revitalization.

While most of the existing literature focuses on the role of immigrant workers in intensive agricultural production, little attention has been given to agriculture systems in more marginal and remote settings: the mountainous territories inner regions and the islands that comprise a large part of the Mediterranean region. Most of the examples and cases reported in this volume refer to the specificities of agro-pastoral systems in the EUMed (Greece, Spain, and Italy), the domain and region which the two authors have researched intensively in recent years. The reconfiguration of agriculture and rural landscapes will be assessed through the lens of agropastoralism; the in-depth exploration of the dynamics surrounding immigrant shepherds will shed light on contemporary phenomena reshaping the agrarian world.

Agro-pastoralism - that is, the extensive rearing of livestock complemented by farming - represents a primary production system in marginal territories and thus the main source of income, employment, and livelihood in areas where more intense and capital-based agriculture is not feasible. In these regions agro-pastoral practices are critical not only for productive purposes, but also to manage landscape and ecological resources and preserve local knowledge of the environment. These are captured by the social and environmental services and benefits associated with agro-pastoral systems and practices.

Despite growing societal appreciation, agro-pastoralism is becoming less and less attractive, especially for young people; shepherding is very demanding, while earnings are meagre. The limited services and facilities available in agro-pastoral territories represent further disincentives for local youth to engage in such activity. In these contexts, immigrants have come to provide skilled labour at relatively low costs. Without foreign workers, many agro-pastoral farms would face great difficulty in pursuing their activities. Evidence shows that immigrants not only participate in productive activities, but they also represent an overall strategic resource for the social and economic development of marginal areas as well as for reproducing local societies.

However, this solution is temporary. Harsh living and working conditions, illegality, and socio-economic vulnerability represent important disincentives for immigrants to remain. Moreover political, economic, and administrative problems provide major constraints and obstacles to the broader integration of rural immigrants. Geographical mobility does not evolve into social mobility; workers face difficulties in scaling up in social and economic terms, with little prospect of eventually graduating as farmers, entrepreneurs, citizens. This raises concerns about the sustainability of the current dynamics as both agricultural farms and rural communities in the EU are facing serious problems of generational renewal and related syndromes of abandonment and socio-economic decline despite the 
consistent "rural welfare" system put in place through the Common Agricultural Policy (CAP).

In the chapters that follow, we undertake a traditional origin-destination perspective to investigate the implications and impacts of rural migratory flows in the different settings. We are aware that more recent and up-to-date approaches on migration studies undertake more fluid and multi-sited perspectives whereby migrants contemporarily inhabit different realities and migration is just part of wider mobility processes. Migrants' agency is nowadays central to how academics theorize migration, how government officials design policies, and how activists devise campaigns to influence policies. However, rather than just focusing on migrants themselves, our focus is on the dynamics and the processes affecting agrarian societies and the rural world.

\subsection{The Plan of the Book}

The book is structured to guide readers through different themes aimed at offering a comprehensive, consistent, and concise set of elements informing the scientific and policy debates on agriculture and rural migrants. Reference to more consistent and elaborated perspectives and analyses is made for the different domains and realities throughout the text.

In the next chapter we analyse the three processes characterizing agriculture and rural areas from the 1950 s to the present: (i) agricultural modernization and polarization; (ii) the restructuring of agri-food chains in the global market; and, (iii) the institutionalization of the agrarian world, including the role of the Common Agricultural Policy (CAP). Our focus is on EUMed countries (Greece, Spain, and Italy), which present some specific and characterising features.

The third chapter focuses on the ambivalent nature of contemporary agricultural migration in European rural areas. The growing presence of immigrants in these areas is a direct result of the restructuring of agriculture and global agri-food chains. Evidence indicates that while agricultural work and rural settings are decreasingly attractive to local populations, they represent a favourable environment to international newcomers as they offer a better chance to access livelihood resources compared to urban areas. The chapter starts by providing a basic understanding of the growing centrality of immigrant workers in agriculture and as citizens of rural communities. The specificities of the Mediterranean migration model are then assessed, followed by a more in-depth analysis of the agricultural sector and the broader rural world in Greece, Spain, and Italy.

In Chap. 4 we provide a framework for assessing and analysing ongoing rural migration dynamics from the perspective of areas of destination, with a view to answering to the following questions: What happens to rural areas of destination? What are the impacts on the local economy and society? Which are the practices, programs, and policies that underpin the presence and integration of migration? What is recent experience revealing on these matters? 
In particular, we focus on the more marginal, isolated, remote areas of the EUMed where the contributions of immigrants are critical for the sustainability and reproduction of local societies. In these areas, immigrant communities could, in fact, represent a strategic asset with an eye to offset processes of rural population decline and abandonment of the agrarian world. The chapter progresses through several cases and experiences related to processes and practices of inclusion and integration of immigrants in Italian settings.

Chapter 5 looks at the implications, impacts, and consequences of rural migration on the areas of origin, where oftentimes portions of the family-and some of its assets - remain. Why do people leave their rural communities? What are the drivers and triggers inducing such emigration? What are the implications for those remaining behind? What are the impacts on local communities and development patterns?

In Chap. 6 we present the specific case of immigrant shepherds in agro-pastoral areas of Greece, Spain, and Italy with a view to unfold and assess the contributions of immigrant communities to the sustainable development of marginal territories.

Final chapter concludes that agriculture and the rural world represent a relevant setting to tackle the challenges linked to the intense migration that is reshaping our societies. Evidence shows that particularly in rural settings, immigrants play a key role in maintaining and reproducing local societies and their embedded heritage. Indeed, the agriculture sector and the rural world hold important potentials for fostering the economic and social integration of migrants and refugees, as attested by the several programs and initiatives we explore.

\subsection{Methodology}

This volume aims at helping students and researchers to evolve the scientific debate around the theme of migrants in rural areas by identifying the main research areas and most important works carried out so far in this domain. It is the result of a research path on which the two authors started in 2014; it combines a review of existing literature with empirical data based on original field research using both quantitative and qualitative methods.

The literature review has been instrumental to unfold the debate about rural migrations and frame the main theoretical questions. Concrete field experiences have been used to support a more empirical understanding of the themes brought to discussion. The use of the "text box" throughout the book helps highlight specific aspects in order to clarify concepts and approaches or to present emblematic empirical cases.

The quantitative and diachronic analysis of data is used to describe the general framework and the main trends. Data used have been mainly sourced from EuroStat, Caritas, Oxfam, the Hellenic Statistical Office (ELSTAT), the Greek Ministry of Migration Policy, the Hellenic Foundation for European and Foreign Policy (ELIAMEP), the Instituto Nacional Estadistico (INE), the Observatorio Mercado 
del Trabajo (OMT), the Observatorio Permanente de la Inmigración (OPI), the Istituto Nazionale di Statistica (ISTAT), the Osservatorio Placido Rizzotto (OPR), the Istituto Nazionale Economia Agraria (INEA) and the Istituto di Servizi per il Mercato Agricolo Alimentare (ISMEA).

The book also presents the results of extensive fieldwork based on qualitative methods such as ethnographic observation, in-depth interviews, and semi-structured questionnaires. These qualitative data have been elaborated through several projects undertaken by the authors on the relations between rural areas and immigration. Main experiences include:

- the EU project Food Track (VP/2016/004) "A transparent and traceable food supply chain for the benefit of workers, enterprises and consumers: the role of a multi-sectoral approach of industrial relations and corporate social responsibility." Funded by European Commission - DG Employment, Social Affairs \& Inclusion. International Coordinator: FILCAMS-CGIL. D. Farinella (University of Cagliari) was coordinator for Italian Research Unit.

- the Open Society European Policy Institute project on immigrants' exploitation in Italian agriculture which investigated the restructuring of agri-food chains and the factors pushing farmers to recruit migrant workers irregularly and thus profiting from their vulnerable conditions. M. Nori collaborated as a research assistant in 2018. The full report of the project is referred to as: Corrado, A., Palumbo L., Caruso F. S., Lo Cascio M., Nori M., Triandafyllidou, A., (2018). Is Italian Agriculture a 'Pull Factor' for Irregular Migration - and, if so, why? Open Society Foundations. It can be accessed at: https://www.opensocietyfoundations. $\mathrm{org} / \mathrm{sites} /$ default/files/is-italian-agriculture-a-pull-factor-for-irregular-migration20181205.pdf

- the Forum on Agriculture, Rural Development and Migration in the Mediterranean, an interagency initiative jointly organised by EUI, FAO, CIHEAM, and UfM to discuss migrations in the Mediterranean from the perspective of rural and agricultural development. The initiative aimed to provide policy recommendations and establish a regional multi-stakeholder platform for decision-makers at different levels. M. Nori was amongst the initiative coordinators in 2017-18. The full report of the initiative is available at http://cadmus.eui.eu/bitstream/handle/ 1814/60473/GGP_RR_2019_01.pdf?sequence=1\&isAllowed=y

- the Strategia Nazionale Aree Interne of the Italian Government (http://old2018. agenziacoesione.gov.it/it/arint/), for which M. Nori is an external collaborator.

The data on the pull and push factors for rural emigrations and on the implications in the communities of migrants' origin refer to:

- the Rural Youth Migration initiative funded by Italian Development Cooperation and FAO and implemented by the EUI Migration Policy Centre. The project aimed to enhance the understanding of rural youth emigration in Tunisia, with a view to facilitating positive impacts on food security, agriculture, and development in rural areas. M. Nori collaborated as a research assistant on the qualitative aspects of the research in 2017 through an innovative, participatory method that 
combined quantitative and qualitative components. The project report is referenced as Zuccotti C.V., Geddes A.P., Bacchi A., Nori M., Stojanov R., 2018. Rural Migration in Tunisia. Drivers and patterns of rural youth migration and its impact on food security and rural livelihoods in Tunisia. Food and Agriculture Organization of the United Nations. Rome. It can be accessed at: http://www.fao.org/rural-employment/work-areas/migration/rym-project/en/.

The section on agro-pastoralism is inspired by:

- the TRAMed - Transhumances in the Mediterranean project, funded by the EU Marie Curie program (contract ES706/2014). The research was concerned with assessing ongoing dynamics affecting pastoralism in the Mediterranean in order to provide a more effective understanding of the presence and contribution of immigrants in this domain, with the view to contribute to the development of appropriate policies at the local and European levels. M. Nori was the project coordinator and principal researcher during the period 2015-2017. D. Farinella was an external collaborator and consultant for the data analysis. During this project, two different sets of semi-structured interviews have been collected with closed and open questions addressed to stockowners (110) and foreign workers (35) in parts of Greece (Peloponnesus and Macedonia), Spain (Cataluña), Italy (Piedmont, Triveneto and Abruzzo), and Provence in France.

- the National Project "Changes of Sardinian pastoralism: shepherds and Romanian workers," funded by the Autonomous Region of Sardinia and the University of Cagliari from 2015 to 2018. D. Farinella was the project coordinator and principal researcher. This project was based on ethnographic observation methods and in-depth interviews (using the technique of collecting life stories) of Sardinian breeders (more than 100) and foreign workers (21).

- The PASTRES project (www.pastres.org), funded by the EU European Research Council, jointly implemented by EUI and IDS of the University of Sussex. M. Nori is a research associate within the project and D. Farinella is an affiliate researcher. Drawing insights from across continents, the project is asking what lessons can we learn for global challenges from pastoral systems responding to uncertainty? In six pastoral regions of the world, the project explores responses to uncertainty in three domains: environment/resources, markets/commodities, and institutions/governance. The challenge is to draw out wider lessons to inform knowledge and decision-making in other societal dimensions where uncertainty is central, including climate and environmental change, financial and commodity markets, response, critical infrastructures, migration policy, and security and conflict. 


\subsection{The Main Theoretical Issues}

Many of the processes and changes described in the book refer to different theoretical and analytical approaches concerning particular issues such as agriculture, rural areas, labour markets, and migration. Without any ambition of completeness, in this section we try to provide the reader with a general framework of these theoretical issues organized by topics.

\subsubsection{Agriculture and the Rural Space}

For decades, the dominant paradigm in agricultural studies and national policies has been agricultural modernization. In the broad context of modernization theory, this paradigm is founded on the idea of development and civilization as a linear and positive transition from "pre-modern," "traditional," and "rural" society to "modern," "industrial," and "urban" (Martinelli 2005; He 2012). Many criticisms can be levelled at this approach, including naive positivism and ethnocentrism (considering Western countries as the one best way of "modernization") (Escobar 1995). The methodological approach combines structural functionalism with the rational actor model and methodological individualism. The research schemes are based on a wide variety of methods, including quantitative methods, testing cause-effect relations, and multivariate analysis.

By the end of the second world war, agricultural modernization theories (see $\mathrm{He}$ 2012: 509-528) promoted the agricultural efficiency as a strategic issue for the economic development of the national states. Agricultural modernization implied the application of scientific principles and technological innovations to agricultural activities, making them rational, replicable, predictable, and efficient. The farmer was supposed to become a rational entrepreneur producing food for the market. The agricultural modernization approach suggested measures as specialization and monoculture, standardization and mechanization, intensification, large-scale and mass production, electrification, irrigation, use of technology, and chemicals and fertilizers. From the 1960s onwards, a specific set of studies introduced the term "green revolution" indicating the application of a wide range of technologies - from genetics to mechanics and chemicals - in "developing" countries to increase farm productivity.

For these theorists, agricultural innovations should have guaranteed mass and low-cost food, solving the difficult balance of food supply and demand in the national States, while bolstering their respective national interests and contributing to social stability. The decline of the percentage of agricultural workers was offset by the increase in their productivity.

Another important requirement of agricultural modernization is neoliberalism: marketization and international trade, commodification of all productive factors 
(land and labour) as well as of agricultural products stimulate the efficiency of local agricultural systems and lower final prices.

After the 1970s, agricultural modernization theories tried to include in the analysis the new challenges posed by the information and biotechnology revolution, the emergence of globalization, and environmental issues. The growing ecological constraints associated with the non-reversible consumption of environmental resources, climate change, pollution, agricultural squeeze, and new exploitation of workers required the adaptation of "development" within "sustainability." Following this path, the new agricultural modernization approach theorizes a sustainable and knowledge-based agriculture, oriented to informatization, renewable energy sources, biotechnologies, and the high-tech revolution. The new studies analyse the ecologization and the transition to green and organic practices, based on diversification and plant-type agriculture (see Christoff 1996; Cohen 1997; Mol 2001).

In contrast with the agricultural modernization approach, in the mid-Seventies, new agri-food studies were stimulated by Marxist tradition and world-system analysis (Wallerstein 1979; Hopkins and Wallerstein 1994). Van der Ploeg's approach of "new peasantries" $(2008,2013)$ considers the "peasant mode of farming" distinctive with respect to entrepreneurial and capitalistic agriculture. "Peasant farming" is a small-scale, familiar, and intensive-labour based model. The peasant model is part of the global market but is in constant struggle for autonomy and to resist commodification, enhancing its internal and redundant elements such as self-production and self-consumption for inputs and outputs, embeddedness in the local environment, coproduction, reciprocity, and non-monetary exchanges, multifunctionality and pluriactivity, and family labour. Following Van der Ploeg (2008:1):

Peasant agriculture "is basically built upon the sustained use of ecological capital and oriented towards defending and improving peasant livelihoods. Multifunctionality is often a major feature. Labour is basically provided by the family (or mobilized within the rural community through relations of reciprocity), and land and the other major means of production are family owned. Production is oriented towards the market as well as towards the reproduction of the farm unit and the family.

The importance of the peasant model is emphasized as a subsistence and autonomy strategy in marginal rural areas, thus highlighting how agro-pastoralism is peasant farming. Other approaches are inspired by the global commodity chains (Gereffi and Korzeniewicz 1990, 1994) and the food regime analysis (Friedmann and McMichael 1989; McMichael 2013), focusing on the role of agriculture in the development of the capitalist world economy and emphasizing the phenomena of accumulation by dispossession related to food relationships in international trade. The incorporation of agriculture into the global supply chains has strengthened the power of corporations and large-scale retail trade in which private forms of regulation prevail. The methodological approach is prevalently based on historical and comparative analysis. As McMichael (2009:140) synthetizes:

the food regime concept historicized the global food system: problematizing linear representations of agricultural modernization, underlining the pivotal role of food in global political-economy and conceptualizing key historical contradictions in particular food regimes that produce crisis, transformation and transition. 
For researchers in this area, the current food regime is based on the "transnational restructuring of agricultural sectors [...] through (i) intensification of agricultural specialization (for both enterprises and regions) and integration of specific crops and livestock into agro-food chains dominated at both ends by increasingly large industrial capitals; and (ii) a shift in agricultural products from final use to industrial inputs for manufactured foods" (Friedmann and McMichael 1989: 105).

The methodological approach is both structural and critical: agriculture and the farmers are the weakest part of a large chain whose components are interrelated and mutually dependent. These researchers analyse the creation and distribution of value into the agri-food supply chains (Burch and Lawrence 2007), focusing on the asymmetries and concentrations of power as well as on the agricultural squeeze.

Another approach is the Rural Development model. This paradigm was developed by OECD, EU, and other transnational institutions. It takes a pragmatic and policy-oriented approach aimed at overcoming the sectorial and productivist approach typical of the classic theories of agricultural modernization (OECD 2006, 2016; Van der Ploeg and Mardsen 2008). In this sense, Rural Development implies a "new developmental model for the agricultural sector" (Van der Ploeg et al. 2000: 392) responding to contemporary challenges, such as, in particular, the rural exodus and land abandonment, the global competition amongst territories, pollution and climate change, the restructuring of the rural economy (with the decrease in agricultural work), and the high-tech revolution.

Rural Development is a post-productivist paradigm: the basic idea is that agriculture is no longer the main source of income and labour in rural regions; the direct correspondence between agriculture and rurality is challenged here, as the latter should be analysed considering its complexity and autonomy. On one hand, rural areas are less competitive in economic and political terms compared to urban settings, especially in times of public spending cuts, but rural population demand the same services as those in urban areas. On the other hand, in a context of globalization and increasingly segmented social demands, rural areas provide services, activities, and products of high ecological and ethical value that are not available in urban areas. In this sense, rural areas have factors of attractiveness for an emerging class of consumers: the rural users.

Another fundamental aspect of the rural development paradigm is multifunctionality in agriculture (OECD 2001; Van Huylenbroeck and Durand 2003; Wilson 2007; Marsden and Sonnino 2008). This refers to the idea that agriculture has other functions in addition to food production and that it produces positive externalities, as in particular non-trade benefits and local collective goods such as ecological services (e.g. environmental protection, landscape management, food security, ecological biodiversity preservation) as well as other goods and services of high value for communities such as tourism services, training, education, and energy.

Following the OECD definition (2006), Rural Development is an integrated, multi-sectoral, place-based and multi-actor approach that aims to exploit the varied and localized potentials of rural areas, supports the empowerment of local communities, and moves from the passive logic of subsidies to the active logic of 
investments. On the methodological level, Rural Development is community-placebased and uses participatory research methods (Chambers 1983).

\subsubsection{Labour Market and Migration Studies}

To explore the dynamics between agriculture and migration in the Mediterranean region we refer to various analytical approaches. The Mediterranean area's capitalism and labour market are framed using suggestions coming from the Varieties of Capitalism (Hall and Soskice 2001; Amable 2003; Molina and Rhodes 2007), and the Welfare State regimes approaches (Esping-Andersen 1990; Ferrera 1996, 2010; Castels et al. 2010).

The Varieties of Capitalism is a theoretical perspective of New Political Economy aimed at comparing different national capitalisms by highlighting the role of economic, political, and institutional factors. The approach is actor-centred and considers the political economy as an arena "populated by multiple actors, each of whom seeks to advance its interests in rational way in strategic interaction with the others" (Hall and Soskice 2001: 6). Specifically, this approach emphasizes the key role of the firm as the agent of adjustments in different aspects of socio-economic life such as corporate governance, labour relations, technological change, and international competition.

The Welfare State regimes literature begins in 1990 with the publication of Esping-Andersen's book The Three Worlds of Welfare Capitalism, in discussion with the earlier contribution of Titmuss (1963). This comparative approach analyses the different ways of organization and functioning of national welfare states. Using Polanyi's theoretical tripartite division (state, market, community) (Polanyi 1944), each local welfare regime is seen as a differentiated combination of these three elements. On the methodological level, it used a comparative method based on categories built according to the Weberian "ideal-type" scheme.

A specific stream of this approach focuses on specificities of the "Latin" or "Mediterranean" model of welfare state and on its transformations (Leibfried 1992; Castles 1993; Ferrera 1996, 2010).

To analyse the Mediterranean labour market and the role of immigrants, we refer in a critical way to the Marxian theory of the Reserve Army. Marx introduced this theory as a general feature of the capitalist system. In his analysis, the "industrial reserve army" is a surplus population of unemployed and potentially available to work (therefore pressing on the workers) as an effect of capitalistic accumulation and change in the capital composition due to mechanization and productivity improvements:

The industrial reserve army, during the periods of stagnation and average prosperity, weighs down the active labour-army; during the periods of over-production and paroxysm, it holds its pretensions in check. Relative surplus population is therefore the pivot upon which the law of demand and supply of labour works. It confines the field of action of this law within the limits absolutely convenient to the activity of exploitation and to the domination of 
capital. [...] Capital works on both sides at the same time. If its accumulation, on the one hand, increases the demand for labour, it increases on the other the supply of labourers by the "setting free" of them, whilst at the same time the pressure of the unemployed compels those that are employed to furnish more labour, and therefore makes the supply of labour, to a certain extent, independent of the supply of labourers (Marx 1974: 598).

In the Marxist analysis, the Reserve Army suggests the labour market is segmented in different sub-groups of workers who are marginal and precarious to varying degrees. Using these suggestions and criticizing the neoclassical approach to the labour market based on the rational actor a group of scholars (Doeringer and Piore 1971; Reich et al. 1973; Harrison and Sum 1979; Piore 1979) in the late 1960s and early 1970 s developed the theory of the dual/segmented labour market. According to this approach, there is a groove between a primary labour market (with high labour productivity) - in which the employers (often unionized) possess high degrees and are guaranteed salaries, labour rights, and stable employment — and a secondary and peripheral labour market comprised of large precarious subsectors characterized by unstable manual and unskilled work with low-productivity and low wages. ${ }^{2}$ The latter represents the weakest social categories such as low-skilled workers, women and youth, and migrants who often are in a subaltern position in the labour market that exposes them to unemployment or under-paid jobs.

Specifically, Castles and Kosack (1973) argue that migrant workers serve as a "reserve army of labour" and Piore (1979) highlights the role of immigrants in segmented labour markets. Making use of quantitative methods and network analysis, many scholars focused on the ethnicitization of some market niches, the migratory chain, as well as the effects of displacement and replacement of migrant labour (Portes and Bach 1985; Portes and Jensen 1989; Waldinger 1994; Waldinger and Lichter 2003; Reyneri 2004; Anderson and Ruhs 2010; Ambrosini 2013; Avola 2015; Fullin 2016). These studies are often accused of considering the migrant only as worker, analysing his "functional" role in the local market.

Another theoretical approach to migration cited in this book is that of the "structural drivers." It is based on the idea there are push and pull factors influencing the migration fluxes. Introduced by Lee (1966), this approach classifies the drivers for migration, distinguishing between those that attract immigrants and those that reject them, leading them to eventually emigrate. As Saitta summarises (2008: 137):

In short, $[\ldots]$ people migrate to a specific country for: a) the characteristics of the area of origin; b) the characteristics of destination area; c) for obstacles that hinder the movement; d) for the internal differentiation of the population (or the social perception of the categories of poverty and wealth). According to Lee, in this framework the analyst's task would be to identify the relevant variables to influence a rational subject to emigrate or stay in a house. Identify these variables, manage the organization within two categories with respect to the decision to leave these determine a negative (push) or positive choice (pull).

\footnotetext{
${ }^{2}$ Furthermore, Esping-Andersen (1999: 111) explains the polarization in the labour market and the entrapment of bad jobs (labour-intensive and low-wage) with "Baumol cost-disease problem" that "will come about because, in the long haul, productivity grows on average much faster in manufacturing than in (most) services."
} 
One of the weaknesses of this neoclassical economic theory and its underlying rational-actor paradigm is its mechanic and direct association between social positions and practices, abstractly assuming that all migrants act the same way.

New perspectives in migration studies evolve from a critique to these deterministic theories, biased by a strong focus on the economic dimension (Massey et al. 1998; Arango 2000; see Kararakoulaki et al. 2018). The limitation of the push/pull approach is that it considers the migration between two countries as driven by a wage gap among geographical areas (Sjaastad 1962; Todaro 1969; Jennissen 2007). In the Marxist approach, the migration is affected by the capitalist development in the global market (Massey et al. 1993). Following the dual labour market theory, in developed countries there is always a demand for migrant workers (Piore 1979; Massey et al. 1993; Jennissen 2007). The main criticism of these theories is "they are overtly focused on why some people move whilst ignoring why others do not, as well as a lack of attention to state policies as influencers of migration. As Arango (2000) notes, migration is "both very complex and straightforward." General explanations are therefore bound to be "reductionistic" (Karakakoulaki et al. 2018: 5).

Another criticism to these theories is that it underestimates migrants' subjectivity and considers them as trapped in a substantive and abstract vision in which they are treated as objects and as quantities. These theories risk to reproduce stereotypes as they often reify migrants' behaviours, activities, and preferences as if these were permanently inscribed in a "sort of biological and cultural essence" (Accardo 2006).

Many recent critical approaches speak of migrant subjectivity in transnational mobility (Anderson 2009; Andrijasevic and Anderson 2009; Conradson and Mckay 2007; Casas-Cortes et al. 2015), using post-colonial suggestions. These studies "investigate the construction of subjectivities in relation to both oppressive and affirmative power dynamics and are working towards a theory of agency that encourages us to think in more nuanced ways about how norms and discourses are inhabited and transformed" (Andrijasevic and Anderson 2009: 366). Many research techniques are based on ethnographies and in-depth interviews.

This book is articulated within this wide theoretical framework.

\section{References}

Accardo, A. (2006). Introduction à une sociologie critique. Lire Pierre Bourdieu. Marseille: Agone.

Amable, B. (2003). The diversity of modern capitalism. Oxford: Oxford University Press.

Ambrosini, M. (2013). Irregular migration and invisible welfare. Basingstoke: Palgrave Macmillan.

Anderson, B. (2009). What's in a name? Immigration controls and subjectivities: The case of au pairs and domestic worker visa holders in the UK. Subjectivity, 29, 407-424.

Anderson, B., \& Ruhs, M. (Eds.). (2010). Who needs migrant workers? Labour shortages, immigration, and public policy. Oxford: Oxford University Press.

Andrijasevic, R., \& Anderson, B. (2009). Conflicts of mobility: Migration, labour and political subjectivities. Subjectivity, 29, 363-366. 
Arango, J. (2000). Explaining migration: A critical view. International Social Science Journal, 52 (165), 283-296.

Avola, M. (2015). The ethnic penalty in the Italian labour market: A comparison between the Centre-North and South. Journal of Ethnic and Migration Studies, 42(11), 1746-1768.

Burch, D., \& Lawrence, G. (2007). Supermarkets and agri-food supply chains transformations in the production and consumption of foods. Cheltenham: Elgar.

Casas-Cortes, M., Cobarrubias, S., De Genova, N., Garelli, G., Grappi, G., Heller, C., Hess, S., Kasparek, B., Mezzadra, S., Neilson, B., Peano, I., Pezzani, L., Pickles, J., Rahola, F., Riedner, L., Scheel, S., \& Tazzioli, M. (2015). New keywords: Migration and Borders. Cultural Studies, 29(1), 55-87. https://doi.org/10.1080/09502386.2014.891630.

Castels, F. G., Leibfried, S., Lewis, J., Obinger, H., \& Pierson, C. (Eds.). (2010). The Oxford handbook of welfare state. Oxford: Oxford University Press.

Castles, F. (1993). Families of nations. Patterns of public policy in Western democracies. Aldershot: Hants.

Castles, S., \& Kosack, G. (1973). Immigrant workers and class structure in Western Europe. London: Institute of Race Relations, Oxford University Press.

Chambers, R. (1983). Rural development: Putting the last first. Harlow: Prentice Hall.

Christoff, P. (1996). Ecological modernisation, ecological modernities. Environmental Politics, 5 (3), 476-500.

Cohen, M. (1997). Risk society and ecological modernisation. Alternative visions for postindustrial nations. Futures, 29(2), 105-119.

Conradson, D., \& Mckay, D. (2007). Translocal subjectivities: Mobility, connection, emotion. Mobilities, Special Issue: Translocal Subjectivities: Mobility, Connection, Emotion, 2(2), 167-174.

Doeringer, P., \& Piore, M. (1971). Internal labor markets and manpower analysis. Lexington: Mass.

Escobar, A. (1995). Encountering development: The making and unmaking of the third world. Princeton: Princenton University Press.

Esping-Andersen, G. (1990). The three worlds of welfare capitalism. Princeton: Princeton University Press.

Esping-Andersen, G. (1999). Social foundations of postindustrial economies. New York: Oxford University Press.

Ferrera, M. (1996). The "Southern Model" of welfare in social Europe. Journal of European Social Policy, 6(1), 17-37.

Ferrera, M. (2010). The South European countries. In Castels et al. (Eds.), The oxford handbook of welfare state (pp. 616-629). Oxford: Oxford University Press.

Friedmann, H., \& McMichael, P. (1989). Agriculture and the state system: The rise and decline of national agricultures, 1870 to the present. Sociologia Ruralis, 29(2), 93-117.

Fullin, G. (2016). Labour market outcomes of immigrants in a South European country: Do race and religion matter? Work Employment and Society, 30(3), 391-409.

Gereffi, G., \& Korzeniewicz, M. (1990). Commodity chains and footwear exports in the semiperiphery. In W. G. Martin (Ed.), Semiperipheral states in the world-economy (pp. 45-68). Westport: Greenwood Press.

Gereffi, G., \& Korzeniewicz, M. (Eds.). (1994). Commodity chains and global capitalism. Westport: Praeger.

Hall, P. A., \& Soskice, D. (2001). Varieties of capitalism: The institutional foundations of comparative advantage. Oxford: Oxford University Press.

Harrison, B., \& Sum, A. (1979). The theory of "dual" or segmented labor markets. Journal of Economic Issues, 13(3), 687-706.

He, C. (2012). Modernization science. In The principles and methods of national advancement. Heidelberg/Dordrecht/London/New York: Springer. 
Hopkins, T. K., \& Wallerstein, I. (1994). Commodity chains: Construct and research. In G. Gereffi \& M. Korzeniewicz (Eds.), Commodity chains and global capitalism (pp. 17-20). Westport: Praeger.

Jennissen, R. (2007). Causality chains in the international migration systems approach. Population Research and Policy Review, 26, 411-436.

Karakoulaki, M., Southgate, L., \& Steiner, J. (2018). Critical perspectives on migration in the twenty-first century. Bristol: E-International Relations.

Lee, E. (1966). A theory of migration. Demography, 3, 47-57.

Leibfried, S. (1992). Towards a European welfare state. In Z. Ferge, \& J. E. Kolberg (Eds.), Social policy in a changing Europe (245-279). Boulder: Westview Press.

Marsden, T., \& Sonnino, S. (2008). Rural development and the regional state: Denying multifunctional agriculture in the UK. Journal of Rural Studies, 24, 422-431.

Martinelli, A. (2005). Global modernization: Rethinking the project of modernity. London: Sage.

Marx, K. (1974 [1867]). Capital (Vol. I). London: Lawrence and Wishart.

Massey, D., Arango, J., Hugo, G., Kouaouci, A., Pellegrino, A., \& Taylor, J. (1993). Theories of international migration: A review and appraisal. Population and Development Review, 19(3), 431-466. https://doi.org/10.2307/2938462.

Massey, D., Arango, J., Hugo, G., Kouaouci, A., Pellegrino, A., \& Taylor, J. (1998). Worlds in motion: Understanding international migration at the end of the millennium. Oxford: Oxford University Press.

McMichael, P. (2009). A food regime genealogy. Journal of Peasant Studies, 36(1), 139-170.

McMichael, P. (2013). Food regimes and agrarian questions. Halifax: Fernwood Publishing.

Mol, A. P. J. (2001). Globalization and environmental reform: The ecological modernization of the global economy. Cambridge: MIT Press.

Molina, O., \& Rhodes, M. (2007). The political economy of adjustment in mixed market economies: A study of Spain and Italy. In B. Hancké, M. Rhodes, \& M. Thatcher (Eds.), Beyond varieties of capitalism: Conflict, contradictions, and complementarities in the European economy (pp. 223-252). Oxford: Oxford University Press.

OECD. (2001). Multifunctionality: Towards an analytical framework. Paris: OECD Publications Service.

OECD. (2006). The new rural paradigm: Policies and governance. Paris: OECD Publications Service.

OECD. (2016). A new rural development paradigm for the 21st century: A toolkit for developing countries. Paris: OECD Publishing. https://doi.org/10.1787/9789264252271-en.

Piore, M. (1979). Birds of passage. Migrant labor and industrial societies. Cambridge: Cambridge University Press.

Polanyi, K. (1944). The great transformation. New York: Farrar \& Rinehart.

Portes, A., \& Bach, R. L. (1985). Latin journey. Cuban and Mexican immigrants in the United States. Berkeley: University of California Press.

Portes, A., \& Jensen, L. (1989). The enclave and the entrants: Patterns of ethnic enterprise in Miami before and Mariel. American Sociological Review, 54, 929-959.

Reich, M., Gordon, D. M., \& Edwards, R. C. (1973). Dual labor markets: A theory of labor market segmentation. American Economic Review, 63(2), 359-365.

Reyneri, E. (2004). Immigrants in a segmented and often undeclared labour market. Journal of Modern Italian Studies, 9(1), 71-93.

Saitta, P. (2008). Tra struttura e funzione. Una critica degli approcci razionalisti in materia di immigrazione. Studi Emigrazione, 169, 135-158.

Sjaastad, L. (1962). The costs and returns of human migration. Journal of Political Economy, 70, 80-93.

Titmuss, R. M. (1963). Essays on 'The welfare state'. London: Unwin University Book.

Todaro, M. (1969). A model of labor migration and urban unemployment in less developed countries. The American Economic Review, 59, 138-148. 
Van der Ploeg, J. D. (2008). The new peasantries. Struggles for autonomy and sustainability in an era of empire and globalization. London: Earthscan.

Van der Ploeg, J. D. (2013). Peasants and the art of farming: A Chayanovian manifesto. Winnipeg: Fernwood Publishing.

Van der Ploeg, J. D., \& Marsden, T. (2008). Unfolding webs: The dynamics of regional rural development. Assen: Royal Van Gorcum.

Van der Ploeg, J. D., Henk Renting, H., Brunori, G., Knickel, K., Mannion, J., Marsden, T., De Roest, K., Sevilla-Guzmán, E., \& Ventura, F. (2000). Rural development: From practices and policies towards theory. Sociologia Ruralis, 40(4), 391-408.

Van Huylenbroeck, G., \& Durand, G. (Eds.). (2003). Multifunctional agriculture: A new paradigm for European agriculture and rural development. Aldershot/Burlington: Ashgate.

Waldinger, R. (1994). The making of an immigrant niche. Intenational Migration Review, 28(1), 3-30.

Waldinger, R., \& Lichter, M. I. (2003). How the other half works: Immigration and the social organization of labor. Berkeley: University of California Press.

Wallerstein, I. (1979). The capitalist world economy. Cambridge: Cambridge University press.

Wilson, G. A. (2007). Multifunctional agriculture. In A transition theory perspective. Trowbridge: Cromwell Press.

Open Access This chapter is licensed under the terms of the Creative Commons Attribution 4.0 International License (http://creativecommons.org/licenses/by/4.0/), which permits use, sharing, adaptation, distribution and reproduction in any medium or format, as long as you give appropriate credit to the original author(s) and the source, provide a link to the Creative Commons license and indicate if changes were made.

The images or other third party material in this chapter are included in the chapter's Creative Commons license, unless indicated otherwise in a credit line to the material. If material is not included in the chapter's Creative Commons license and your intended use is not permitted by statutory regulation or exceeds the permitted use, you will need to obtain permission directly from the copyright holder.

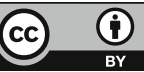

